\title{
Neotropical Monogenoidea 59. Polyonchoineans from Characidium spp. (Characiformes: Crenuchidae) from southern Brazil
}

\author{
Walter A. Boeger ${ }^{1}$, Renata C. Ferreira ${ }^{1}$, Rogério T. Vianna $^{2}$ and Luciana Patella ${ }^{1}$ \\ ${ }^{1}$ Laboratório de Ecologia Molecular e Parasitologia Evolutiva, Department de Zoologia, Universidade Federal do Paraná, Curitiba, \\ Paraná, Brazil; \\ ${ }^{2}$ Laboratório de Ictioparasitologia e Sistemática, Universidade Federal de Santa Catarina, Campus Curitibanos, Curitibanos, Santa \\ Catarina, Brazil
}

\begin{abstract}
Gyrodactylidae and Dactylogyridae (Monogenoidea) are described or reported from three species of Characidium Reinhardt (Crenuchidae), small species of Characiformes, from streams located in southern Brazilian states. Gyrodactylus carolinae sp. n. (Gyrodactylidae) is described from the body surface of Characidium lanei Travassos (type host), C. pterostictum Gomez, and Characidium sp. from streams in the states of Paraná and São Paulo. This new species closely resembles species of Gyrodactylus von Nordmann, 1832 described from species of Poeciliidae, from which it differs by the morphology of the hooks and nucleotide sequences of ITS1-5.8S-ITS2 rDNA. Gyrodactylus inesperatus sp. n. is described from the body surface of Characidium sp. from a stream in the State of São Paulo. The latter new species is characterised by lacking a shield on the superficial bar and by the morphology of the hooks, both unique characteristics for Neotropical species of Gyrodactylus. Marumbius gen. n. (Dactylogyridae) is proposed to accommodate two species, $M$. dorsivaginatus sp. n. from the gills of Characidium pterostictum (type host) and $C$. lanei, and M. amplexus sp. $\mathrm{n}$. from the gills of $C$. lanei (all from the state of Paraná). Both species are characterised by having dorsal vagina, hook pairs 2-4, 6 and 7 composed by two subunits, hook pairs 1 and 5 lacking proximal subunit, and by the length of proximal subunits (when present) varying among hook pairs, completely or partially overlapping gonads, and male copulatory organ (MCO) represented by an incomplete coil of a sclerotized tube articulated to the accessory piece by a copulatory ligament. Cacatuocotyle paranaensis Boeger, Domingues et Kritsky, 1997 is reported from C. lanei at low prevalence in the Rio Marumbi (state of Paraná). The Monogenoidea that parasitize species of Characidium are members of several independent lineages, some of distant evolutionary relationships, suggesting a complex origin for this parasitic fauna.
\end{abstract}

Keywords: taxonomy, Gyrodactylus, Marumbius gen. n., Gyrodactylus carolinae sp. n., Gyrodactylus inesperatus sp. n., Marumbius dorsivaginatus sp. n., Marumbius amplexus sp. n., Neotropical region

Freshwater Monogenoidea is by far the best known group of metazoan fish parasites in Brazil and in the Neotropical region, with more than 400 species described from continental waters (Eiras et al. 2011). However, the diversity of the group is far from being well characterised. Most of what is known about the diversity of Monogenoidea in the Neotropics is derived from studies on mediumto relatively large-sized fish species. Small species, especially small species of Characiformes and Siluriformes, are likely parasitized by presently undescribed species of often-undisclosed higher categories.

Thus, in this study, species of Gyrodactylidae and Dactylogyridae are described or reported from three species of Characidium Reinhardt (Crenuchidae), small species of Characiformes from streams located in the southern states of São Paulo and Paraná. Two species of Gyrodactylus von Nordmann, 1832 (Gyrodactylidae) are described and Marumbius gen. n. (Dactylogyridae) is proposed to accommodate two new species. Previous to this study, only
Urocleidoides anops Kritsky et Thatcher, 1974 and $\mathrm{Ca}$ catuocotyle paranaensis Boeger, Domingues et Kritsky, 1997 were known to parasitize species of Characidium from Colombia and Brazil, respectively (Kritsky and Thatcher 1974, Boeger et al. 1997).

\section{MATERIALS AND METHODS}

Host fish were captured from small coastal streams of the states of Paraná and São Paulo. Fish were captured with seine nets and electronarcosis, euthanized by pitting and placed immediately in hot water (about $65^{\circ} \mathrm{C}$ ). Parasite specimens were immediately preserved either in ethanol $(70-80 \%)$ or $5 \%$ formalin for subsequent processing. Fish hosts were preserved in $70-80 \%$ ethanol. Vouchers of the host species (symbiotypes as defined by Brooks 1993) are deposited in the ichthyological collection of the Museu Capão da Imbuia, Curitiba, Brazil as follow: Characidium lanei Travassos (MHMCI 13012); Characidium pterostictum Gomez (MHMCI 13013); and the unidentified Characidium sp. (MHNCI 13026). 
Table 1. New and available sequences for Gyrodactylus spp.

\begin{tabular}{|c|c|c|c|}
\hline & GenBank No. & USNPC No. & Reference \\
\hline Gyrodactylus alexgusevi Zietara et Lumme, 2003 & AY061979 & - & Zietara and Lumme (2003) \\
\hline Gyrodactylus arcuatoides Huyse, Malmberg et Volckaert, 2004 & AY338429 & - & Huyse et al. (2003) \\
\hline Gyrodactylus arcuatus Bychowsky, 1933 & JN703797 & - & Hansen et al. (2012) \\
\hline Gyrodactylus carolinae sp. n. & KF673399 & HWML 49860 & Present study \\
\hline Gyrodactylus carolinae sp. $\mathrm{n}$. & KF673400 & USNPC 107218 & Present study \\
\hline Gyrodactylus carolinae sp. n. & KF673402 & USNPC 107182 & Present study \\
\hline Gyrodactylus carolinae sp. n. & KF673403 & - & Present study \\
\hline Gyrodactylus carolinae sp. $\mathrm{n}$. & K673401 & USNPC 107217 & Present study \\
\hline Gyrodactylus gondae Huyse, Malmberg et Volckaert, 2004 & AF328866 & - & Zietara et al. (2002) \\
\hline Gyrodactylus harengi Malmberg, 1957 & AJ576064 & - & Huyse and Malmberg (2004) \\
\hline Gyrodactylus lotae Gusev, 1953 & AY061978 & - & Zietara and Lumme (2003) \\
\hline Gyrodactylus lotae Gusev, 1953 & EF446730 & - & Zietara et al. (2008) \\
\hline Gyrodactylus lotae Gusev, 1953 & EF446731 & - & Zietara et al. (2008) \\
\hline Gyrodactylus pictae Cable, Oosterhout, Barson et Harris, 2005 & AY692023 & - & Cable et al. (2005) \\
\hline Gyrodactylus turnbulli Harris, 1986 & AJ001846 & - & Cable et al. (1999) \\
\hline Gyrodactylus turnbulli Harris, 1986 & EF445942 & - & unpublished \\
\hline
\end{tabular}

In the laboratory, parasites were collected from the sediment using a small probe under a dissecting microscope. Gills were removed from the fish, shaken and parasites were collected as described above. Some specimens were stained with Gomori's trichrome and mounted in Canada balsam for study of their soft anatomy; other specimens were cleared and mounted in Hoyer's or Gray and Wess' media for study of their sclerotized structures (all solutions prepared as in Humason 1979). Illustrations were prepared with the aid of a camera lucida on an Olympus BX51 microscope equipped with phase contrast.

Measurements, all in micrometres, were made following the procedures of Mizelle and Klucka (1953) for Dactylogyridae and Kritsky et al. (1995) for Gyrodactylidae; the mean is followed by the range and the number of structures measured (n) in parentheses; body length includes that of the haptor (longitudinal axis of haptor added to that of body proper). Length of the male copulatory organ (MCO) of Dactylogyridae represents the distance between bars in respective figures. Numbering of the hook pairs follows that recommended by Mizelle (1936) and Mizelle and Price (1963). Haptoral terminology is that provided by Mizelle and Kritsky (1967) and Kritsky and Mizelle (1968). Prevalence values are presented as the percentage of parasitized hosts followed by the number of parasitized host/total number of sampled hosts between parentheses.

Individual specimens of a new species of Gyrodactylus, preserved in ethanol, were placed in glycerine on a microscope slide and the haptoral extremity was cut with a fine blade. The haptoral portion was mounted in Hoyer mounting medium $(\mathrm{Hu}-$ mason 1979) for species identification and to serve as vouchers. DNA was extracted from the anterior portion of the worm using the DNAEasy tissue kit (Qiagen, Hilden, Germany). The primers ITS1 (5'-TTTCCGTAGGTGAACCT-3') and ITS2 (5'-TCCTCCGCTTAGTGATA-3'), of Cunningham (1997) were used to amplify and sequence the fragments ITS1, 5.8S and ITS 2 .

The polymerase chain reaction (PCR) was performed with the following program: initial denaturation at $94^{\circ} \mathrm{C}$ for $5 \mathrm{~min}$ followed by 40 cycles as follows: denaturation at $94^{\circ} \mathrm{C}$ for $1 \mathrm{~min}$, annealing at $50^{\circ} \mathrm{C}$ for $1 \mathrm{~min}$, extension at $72^{\circ} \mathrm{C}$ for $1 \mathrm{~min}$, and final extension $72^{\circ} \mathrm{C}$. PCR was achieved in $25 \mu$ l containing 10-30 ng of template DNA, $3 \mathrm{mM} \mathrm{MgCl}, 1 \times$ PCR-Buffer (Invitrogen, Carlsbad, CA, USA), 0.5 pmoles of each primer,
$0.4 \mathrm{mM} \mathrm{dNTP}$, and 1U Platinum Taq polymerase (Invitrogen) in a total volume of $25 \mu 1$. Confirmation of the amplification of the fragments by PCR was achieved through electrophoresis in a $1.5 \%$ agarose gel, subsequent staining in ethidium bromide and visualization under UV light. Amplicons were purified using the MinElute Purification kit (Qiagen). Sequences were obtained with the BigDye 3.1 chemistry in the 3130 DNA Analyser with the same program and primers used during amplification. Sequences were edited using Geneious 5.0.4 (created by Biomatters; available from http://www.geneious.com/).

Alignment of the sequences was obtained using the algorithm MUSCLE (Edgar 2004) within Geneious 5.0.4. Distance analysis (Neighbor Joining) was performed with the software MEGA version 5 (Tamura et al. 2011) using the model Maximum Composite Likelihood (Nei and Kumar 2004) removing ambiguous positions for each sequence pair and bootstrap support of 1000 repetitions. Sequences included in the distance analysis were the sequences produced in this study, sequences of Neotropical and non-Neotropical species that systematically clustered together in the distance analysis of NCBI-BLAST (Altschul et al. 1997). Further, sequences of arbitrarily chosen Neotropical species and sequences of other non-Neotropical species presenting morphological similarity to the new species were selected from GenBank (Table 1).

The resulting phylogram from the neighbor-joining analysis is intended to represent intra- and interspecific distances but not phylogenetic relationships. This decision is based on the fact that, among other things, alignment of fragments of ITS 1 and ITS 2 is often difficult due to abundant indel regions (see Álvarez and Wendel 2003). Thus, except for the included 5.8S rDNA region, this fragment has limited reliability in phylogenetic reconstructions without consideration of homologies of its secondary structure among included taxa (Coleman 2007), especially if distant taxa are considered.

Type specimens and vouchers were deposited in the United States National Parasite Collection (USNPC), Beltsville, USA; University of Nebraska State Museum, Harold W. Manter Laboratory (HWML), Lincoln, USA; Helminthological Collection of the Institute of Parasitology, Biology Centre of the Academy of Sciences of the Czech Republic, České Budějovice, Czech Republic (IPCAS); and the Parasitological Collection of the In- 
stituto Oswaldo Cruz, Rio de Janeiro, Brazil (CHIOC), as indicated in the respective species accounts.

\section{RESULTS}

Class Monogenoidea Bychowsky, 1937

Subclass Polyonchoinea Bychowsky, 1937

Order Gyrodactylidea Bychowsky, 1937

Family Gyrodactylidae van Beneden et Hesse, 1863

Gyrodactylus carolinae sp. n.

Figs. 1-5, 30, 31, 33

Description (based on 27 specimens - all from the State of Paraná): Body elongate, $431(\mathrm{n}=1)$ long, 73 $(\mathrm{n}=1)$ wide. Cephalic glands, head organs, spike sensilla conspicuous. Cephalic glands anterolateral, lateral, posterolateral to pharynx. Excretory vesicles, pores lateral to oesophagus. Pharynx composed of two tandem bulbs; distal pharyngeal bulb muscular, $32(\mathrm{n}=1)$ wide; digitiform projections of distal pharyngeal bulb not observed; proximal pharyngeal bulb glandular, $38(\mathrm{n}=1)$ wide.

MCO $18(\mathrm{n}=1)$ wide, armed with one spine, one row of 4-6 spinelets; spinelets similar in shape and size, each with wide, truncate base. Testis ovate $25(n=1)$ wide, posterior to germarium. Germarium ovate, $14(n=1)$ long, $21(\mathrm{n}=1)$ wide. Uterus with up to two generations of embryos. Large syncytial glandular mass overlapping distal midlength of caeca.

Anchor 55 (50-67; $\mathrm{n}=25)$ long; shaft straight, recurved point $18(16-20 ; n=16)$; deep root poorly developed, knob-like; superficial root elongate. Superficial bar $10(9-12 ; n=3)$ long, $49(45-51 ; n=3)$ wide, with two robust, elongate anterolateral projections; shield subtriangular, striated. Deep bar constricted near midlength and at attachment of deep bar to anchor. Hooklet with straight shaft, point recurved; heel convex; toe slightly pointed, depressed; shelf convex; hook shank proximally bulbous; hook $25(23-28 ; n=15)$ long; hooklet $6(6-8 ; n=25)$ long. Long unicellular glands in peduncle with ducts directed to haptoral region.

Type host: Characidium lanei Travassos.

Other host: Characidium pterostictum Gomez and Characidium sp.

Site of infection: Body surface.

Type locality: Rio Marumbi, municipality of Morretes,

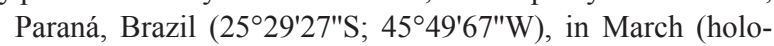
type collected on 18 March 2010) and August 2010 and May 2011.

Other localities: Rio do Nunes, municipality of Antonina, Paraná, Brazil $\left(25^{\circ} 20^{\prime} 37^{\prime \prime} \mathrm{S}\right.$; $\left.48^{\circ} 45^{\prime} 59^{\prime \prime} \mathrm{W}\right)$, in May 2005; Rio das Conchas ( $24^{\circ} 9^{\prime} 24^{\prime \prime S}$; $\left.48^{\circ} 18^{\prime} 4^{\prime \prime} \mathrm{W}\right)$, in November 2003, Rio das Almas (24ㅇ' $8^{\prime} 51^{\prime \prime S}$; $\left.48^{\circ} 20^{\prime} 52^{\prime \prime} \mathrm{W}\right)$, Ribeirão Bonito, São Paulo, Brazil, in November 2003.

Prevale n c e: Characidium pterostictum 28\% (19/67); C. lanei 23\% (18/79); (not available for Characidium sp.).

Specimens studied: Holotype (CHIOC 37880); 25 paratypes (CHIOC 37875-37879, 37900; USNPC 107182 107189, 107217, 107218; HWML 49859-49862; IPCAS $\mathrm{M}-541)$

Etymology: The species is named after Carolina Souza Nascimento, a wonderful girl that left us unexpectedly at the age of 21 , before fulfilling all her potential as a student of Monogenoidea.

Remarks. Gyrodactylus carolinae sp. n. is clearly a member of a wider group of species from the Neotropical region composed by G. bullatarudis Turnbull, 1956; G. costaricensis Kritsky et Fritts, 1970; G. jarocho Rubio-Godoy, Paladini, García-Vásquez, Shinn, 2010; G. milleri Harris et Cable, 2000; G. pictae Cable, Oosterhout, Barson et Harris, 2005; G. poeciliae Harris et Cable, 2000; G. rasini Lucký, 1973, G. turnbulli Harris, 1986; and G. xalapensis Rubio-Godoy, Paladini, GarcíaVásquez, Shinn, 2010, as suggested by the comparative morphology of hard parts and, whenever known, by the pattern in the armature of the male copulatory organ (MCO).

Except for the new species, all remaining species are parasites of poeciliid fish (Cyprinodontiformes). The anchor of these species usually presents superficial bar with pronounced anterolateral projections. The armature of the MCO, whenever described, has just a single row of spinelets, usually in small numbers (4-6), and a large spine. In general, these characters are reminiscent of the species placed in Malmberg's (1970) subgenus Mesonephrotus, which includes marine, brackish and freshwater species from other biogeographic realms.

Among the Neotropical species, G. carolinae most closely resembles $G$. bullatarudis by presenting great similarity in the morphology of all hard parts, including the armature of the MCO (see Kritsky and Fritts 1970). Both species depict a small number of spinelets on the MCO, deep bar with a notch near midlength and superficial bar with a shield tapering distally. The distinct morphology of the hooks, however, allows their differentiation (see Fig. 6). The hooks of G. carolinae present a more robust shaft, longer point, more delicate base of the hooklet and rounder heel.

The new species differs from the remaining members of the above-mentioned group of morphologically similar Neotropical species especially by the morphology of the hook (see Fig. 6). The point of G. carolinae is relatively longer and the base of the hooklet is more delicate than those of G. costaricensis, G. poeciliae and G. bullatarudis. The new species also differs from G. pictae, G. milleri and $G$. turnbulli by having a more robust base and shaft, and a point forming a more acute angle with the shaft. Further, the hooks of G. jarocho, G. xalapensis and $G$. rasini present a conspicuously wavy tip of the point (see Richards et al. 2000, Rubio-Godoy et al. 2010), whereas the point of $G$. carolinae is straight, as in the remaining species of this group. 
1

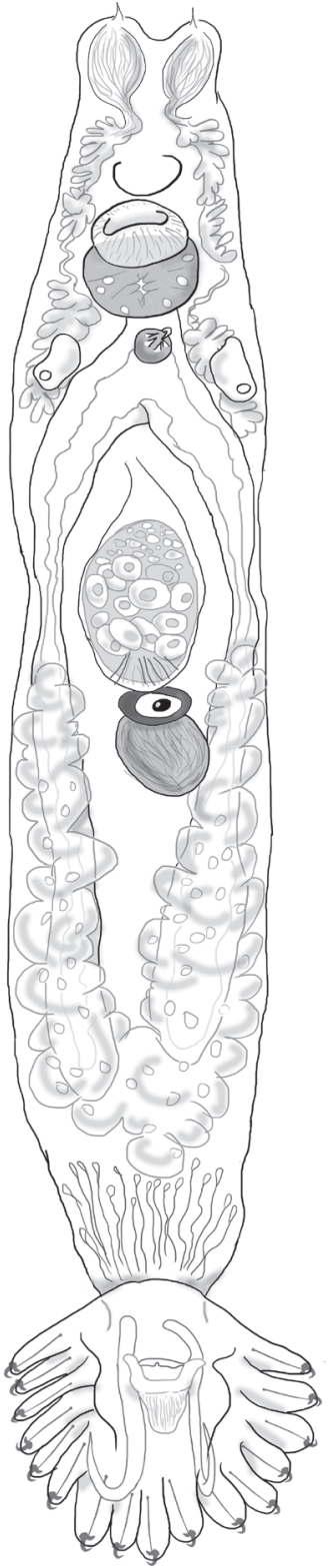

3

2

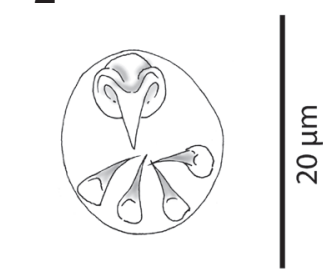

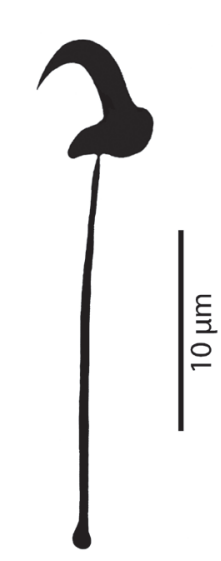
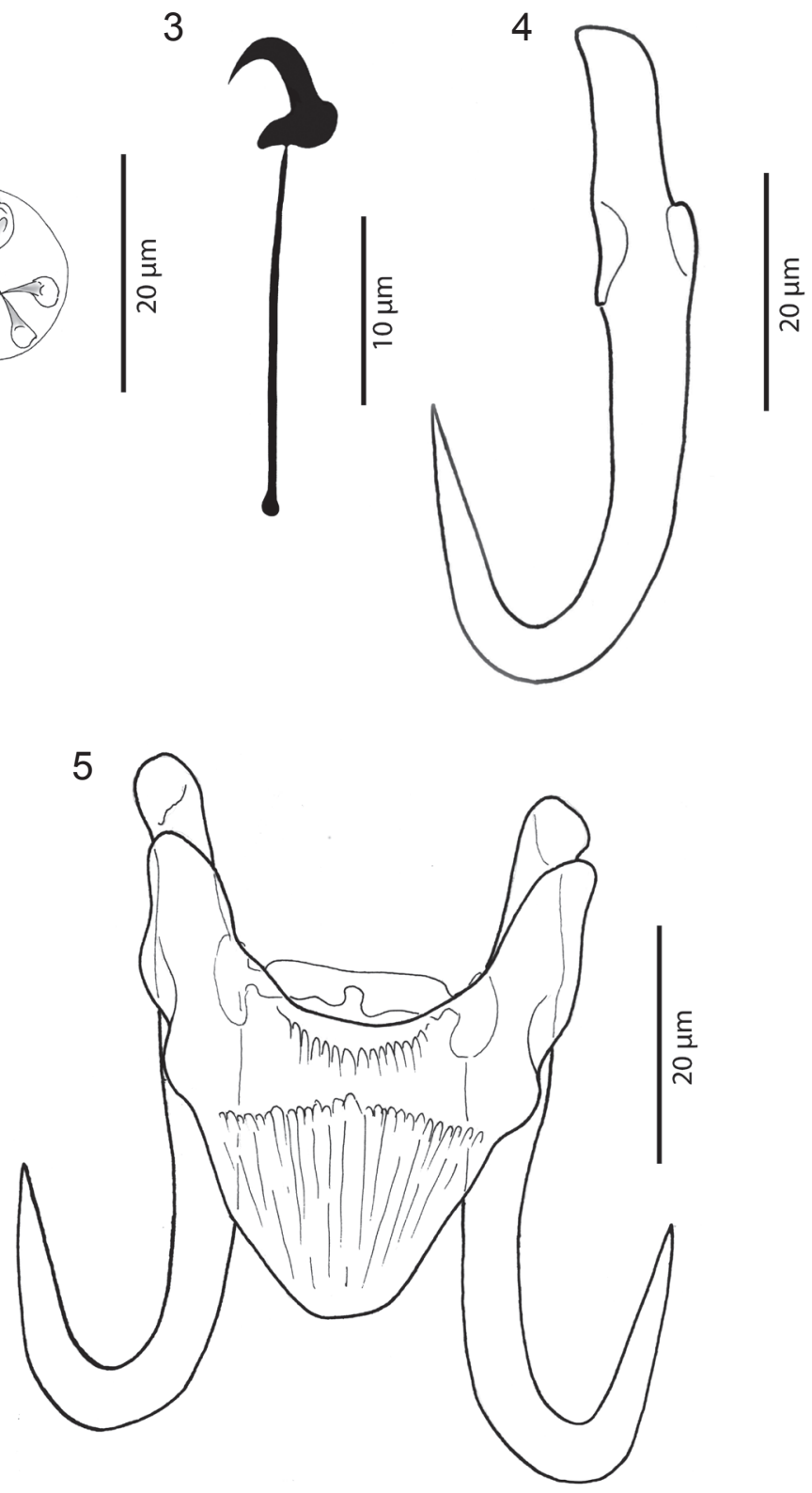

Figs. 1-5. Gyrodactylus carolinae sp. n. from Characidium pterostictum. Fig. 1. Holotype (ventral view). Fig. 2. Male copulatory organ. Fig. 3. Hook. Fig. 4. Ventral anchor. Fig. 5. Anchor-bars complex.

Further support to the identity of the new species is derived from the pairwise comparison of ITS1-5.8S-ITS2 rDNA sequences. Sequences of specimens of G. carolinae cluster in a single group and present intraspecific distances much shorter than the interspecific genetic distances observed among studied sequences (Table 2; Fig. 6). Individuals of a same species should cluster in a single clade depicting small differences (distance) in nucleotide composition - supporting monophyly of the species proposed/evaluated - whereas similar groups (other species) should present greater genetic distances among them - revealing the identity and individuality of distinct species. Under these premises, molecular analyses intended to test the proposal or recognition of species would necessarily incorporate more than one individual. For cytochrome oxidase I, e.g. the Fish Barcode of Life Initiative suggests between 5-25 individuals of each species, depending on the species distribution (Steinke and Hanner 2011).

This, however, is not a widespread practice and molecular support for new species of Gyrodactylidae is often based solely on phylogenic hypotheses or an analysis of genetic distances using a single specimen for each putative OTU (Organizational Taxonomic Unit) (e.g. Cable et al. 2005, Paladini et al. 2011), or simply incorporates a description of the nucleotide composition of a fragment of ribosomal DNA (e.g. Vaughan et al. 2010) Undoubtedly, these procedures provide information on the phylogenetic position of the specimens under study and some support 


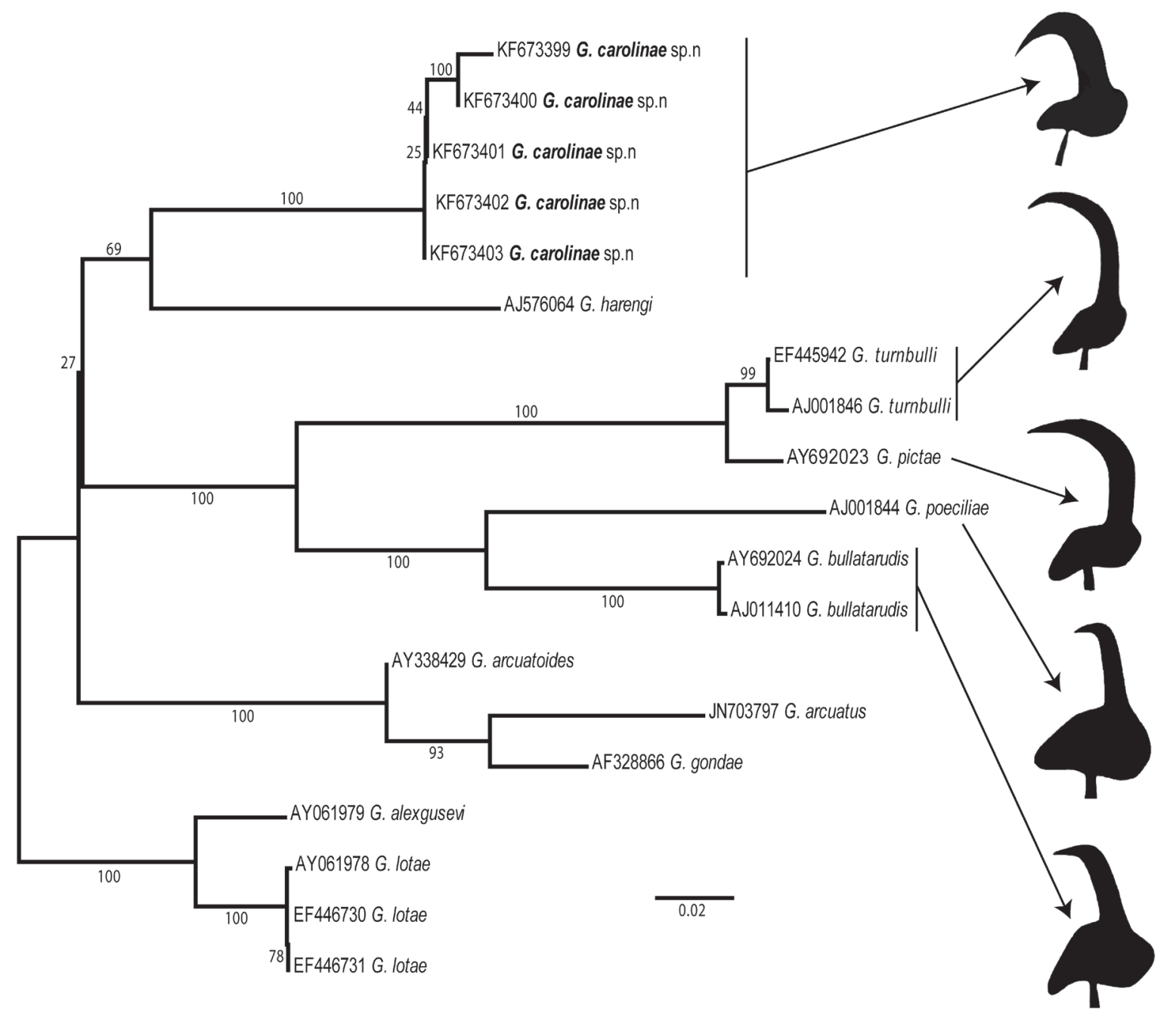

Fig. 6. Neighbor-joining phylogram of selected species of Gyrodactylus based on the Maximum Composite Likelihood (Nei and Kumar 2004) model for ITS1-5.8 S-ITS2 rDNA to represent intra- and interspecific distances. Bootstrap values $(\mathrm{n}=1000)$ are presented below each respective branch if above 50. Profile of hooklets of selected species is presented (not to the same scale).

for the proposal of a new species, but they do not satisfy the criteria of identity and monophyly mentioned above.

\section{Gyrodactylus inesperatus sp. n.}

Figs. 7-11, 34

Description (based on 11 specimens): Body elongate, $421(388-474 ; \mathrm{n}=3)$ long, $71(62-86 ; \mathrm{n}=3)$ wide. Cephalic glands, head organs, spike sensilla conspicuous. Cephalic glands anterolateral, lateral, posterolateral to pharynx. Large excretory vesicles lateral to oesophagus. Pharynx composed of two tandem bulbs; distal pharyngeal bulb muscular $30(26-35 ; \mathrm{n}=3)$ wide; digitiform projections of distal pharyngeal bulb not observed; proximal pharyngeal bulb glandular 31-36 $(\mathrm{n}=2)$ wide.

MCO $11(n=1)$ wide, armed with one spine, one row of four large and four small spinelets; each spinelet with wide, truncate base. Testis ovate $17-25(\mathrm{n}=2)$ wide, posterior to germarium. Germarium ovate, $22-23(\mathrm{n}=2)$ long, 24-25 ( $\mathrm{n}=2)$ wide. Uterus with up to two generations of embryos. Large syncytial mass overlapping distal extremity of caeca; unicellular glands distributed in limited region posterior to testis.

Anchor 40-43 ( $\mathrm{n}=2)$ long; straight shaft; deep root poorly developed, knob-like; superficial root short, robust; articulation of superficial bar expanded, subovate. Superficial bar 10-15 ( $\mathrm{n}=2)$ long, $7(\mathrm{n}=2)$ wide, with two short anterolateral projections; shield absent. Deep bar rod-shaped. Hooklet with straight, robust shaft, point short about $90^{\circ}$ to shaft; heel subrectangular; toe slightly erected, blunt; shelf short, straight; shank tapering distally, $17(16-18 ; \mathrm{n}=4)$ long; hooklet $7(n=4)$ long. Long unicellular glands in peduncle with ducts directed to haptoral region.

Type host: Characidium sp.

Type locality: Rio das Almas, Ribeirão Bonito, São

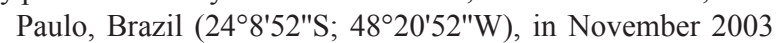
(holotype collected on 8 November 2003).

Site of infection: Body surface.

Prevalence: $100 \%(2 / 2)$

Specimens studied: Holotype (CHIOC 37869); 10 para- 
Table 2. Pairwise genetic distances between selected species of Gyrodactylus based on the fragment ITS 1-5.8S-ITS2 rDNA. The number of base substitutions per site from between sequences are shown. Analyses were conducted using the Maximum Composite Likelihood (Nei and Kumar 2004) model. All ambiguous positions were removed for each sequence pair.

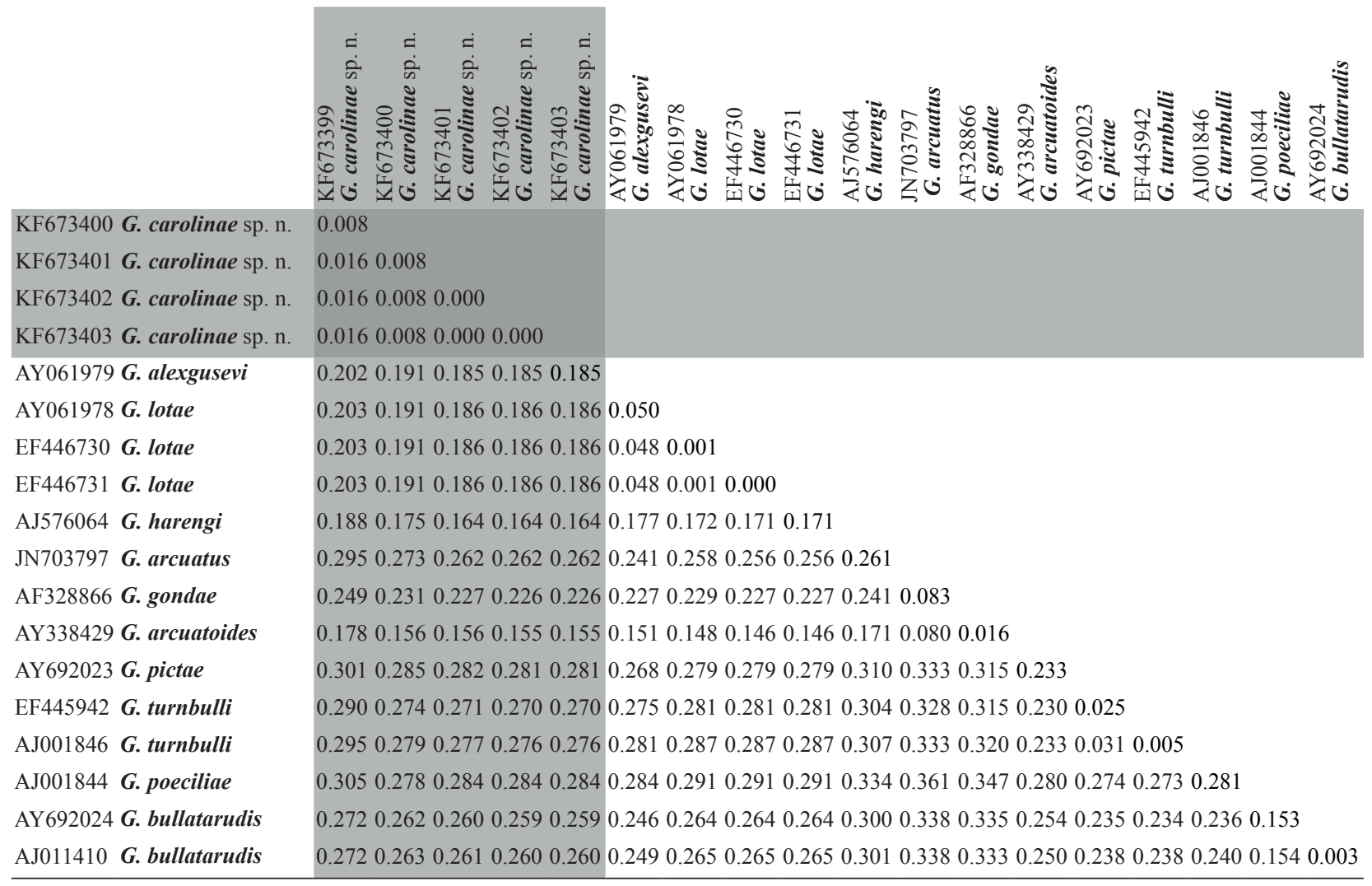

types (CHIOC 37870-37874; USNPC 107190; HWML 49863; IPCAS M - 542).

Etymology: The specific name refers to the fact that the species unexpectedly (= inesperatus in Latin) lacks a shield, a structure widely common among viviparous species of Gyrodactylidae.

Remarks. Contrary to all other species of Neotropical freshwater Gyrodactylus, G. inesperatus sp. n. lacks a shield on the superficial bar. The absence of the shield in several species of Gyrodactylus may be in fact result of incomplete descriptions due to the fact that the shield may become greatly transparent during slide preparation or even 'shrink' due to interaction with mounting medium. Indeed, shrinking of the shield has been observed in specimens of Gyrodactylus sp. from Astyanax sp. (Characidae) mounted in Hoyer's mounting medium (W. Boeger - unpublished data). Other species, however, appear to actually lack the shield and this absence may be both by retention of a primitive character state (as observed in the oviparous Gyrodactylidae; Boeger et al. 1994) or by secondary loss.

Thus, the absence of the shield should be confirmed always by additional methods, such as scanning electron microscopy or by adequate slide specimen preparation for light microscopy. The absence of the shield in G. inesperatus was confirmed in all specimens stained with Gomori's trichrome and mounted in Canada balsam (see Kritsky et al. 1978 for the method). Gomori's trichrome is known to stain some haptoral structures, resulting in a more conspicuous shield that can be easily observed under optical light microscopy. Other options are any of several similar techniques developed for light or confocal microscopy (e.g. Kritsky et al. 1978, Richards and Chubb 1995, García-Vásquez et al. 2012).

In addition, the hook morphology of $G$. inesperatus is distinct from that of any other Neotropical species and hooks present a robust, straight shaft, a short robust point forming about $90^{\circ}$ with the shaft and a subrectangular heel and toe.

Order Dactylogyridea Bychowsky, 1937

Family Dactylogyridae Bychowsky, 1933

Subfamily Ancyrocephalinae Bychowsky, 1937

Marumbius gen. n.

Diagnosis: Body fusiform, slightly flattened dorsoventrally, comprising body proper (cephalic region, trunk, peduncle) and haptor. Tegument smooth. Four cephalic 

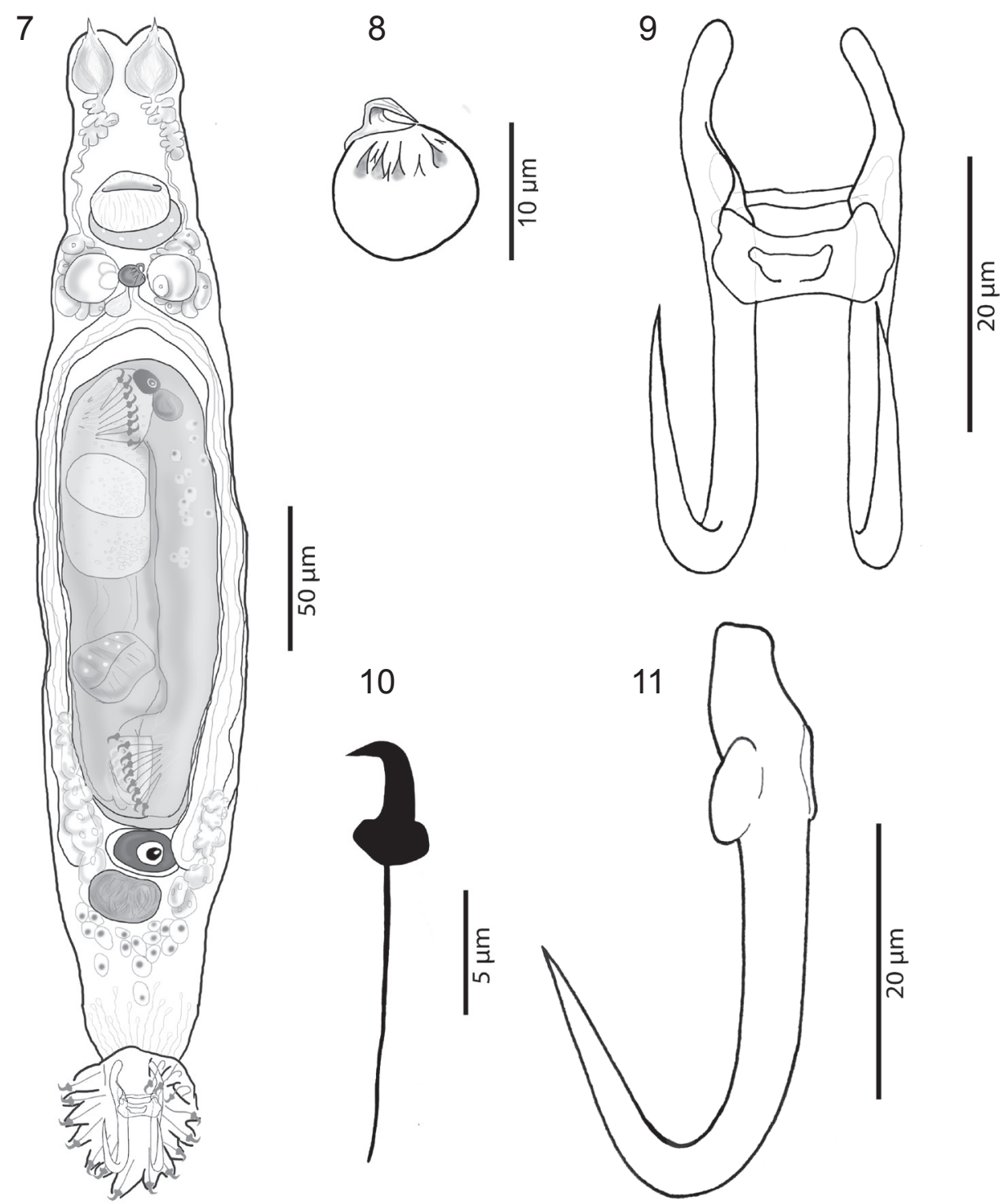

Figs. 7-11. Gyrodactylus inesperatus sp. n. from Characidium sp. Fig. 7. Holotype (ventral view). Fig. 8. Male copulatory organ. Fig. 9. Anchor-bars complex. Fig. 10. Hook. Fig. 11. Ventral anchor.

lobes; pairs of bilateral head organs; cephalic glands unicellular, lateral or posterolateral to pharynx. Eyespots four; granules small, ovate. Mouth subterminal, midventral, prepharyngeal; pharynx muscular, glandular; oesophagus short or inconspicuous; intestinal caeca two, confluent posterior to gonads, lacking diverticula.

Common genital pore midventral at level of intestinal bifurcation. Gonads intercaecal, completely or partially overlapping; germarium ventral to testis. Vas deferens looping left intestinal caecum; seminal vesicle a simple dilation of vas deferens. Copulatory complex comprising $\mathrm{MCO}$ and accessory piece. MCO sclerotized, tubular. Accessory piece serving as guide for distal portion of $\mathrm{MCO}$, articulated to MCO base by copulatory ligament. Seminal receptacle pregermarial; vaginal pore single, dorsal, intercaecal; vaginal duct intercaecal; vagina nonsclerotized or distally sclerotized; vaginal opening sclero- tized or non-sclerotized. Vitellaria in trunk, absent from regions of other reproductive organs. Peduncle short to inconspicuous. Haptor armed with dorsal and ventral anchor/bar complexes, seven pairs of similar hooks. Hook distribution ancyrocephaline (see Mizelle 1936); shank of hook pairs 1, 5 comprising a single subunit; shank of hook pairs 2-4, 6, 7 comprising 2 subunits; length of proximal subunits varies according to hook pair. Parasites of the gills of Neotropical Crenuchidae (Teleostei).

Ty p e s pecies: Marumbius dorsivaginatus sp. n. O the r s pecies: Marumbius amplexus sp. n.

Ety m o log y: The generic name makes reference to the river from which the type species was collected, the Rio Marumbi.

Remarks: Marumbius gen. n. is proposed to accommodate species of Neotropical Dactylogyridae presenting the combined diagnostic characteristics: dorsal vagina, 

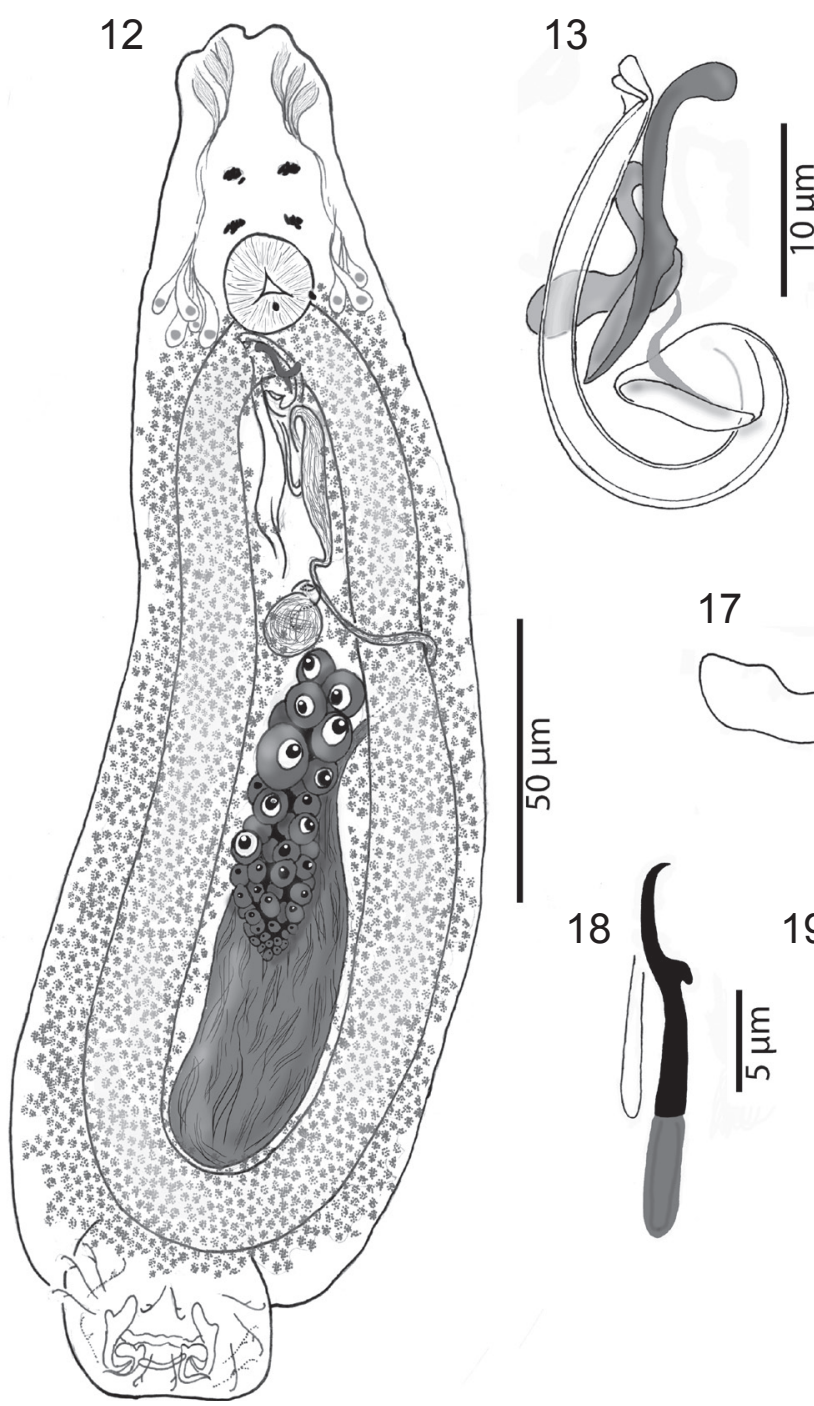

14
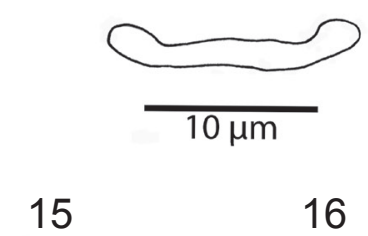

16

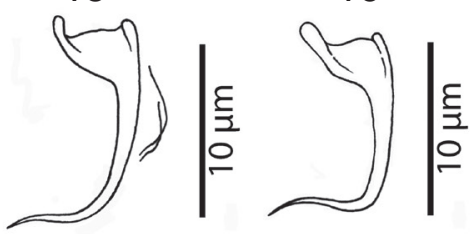

17
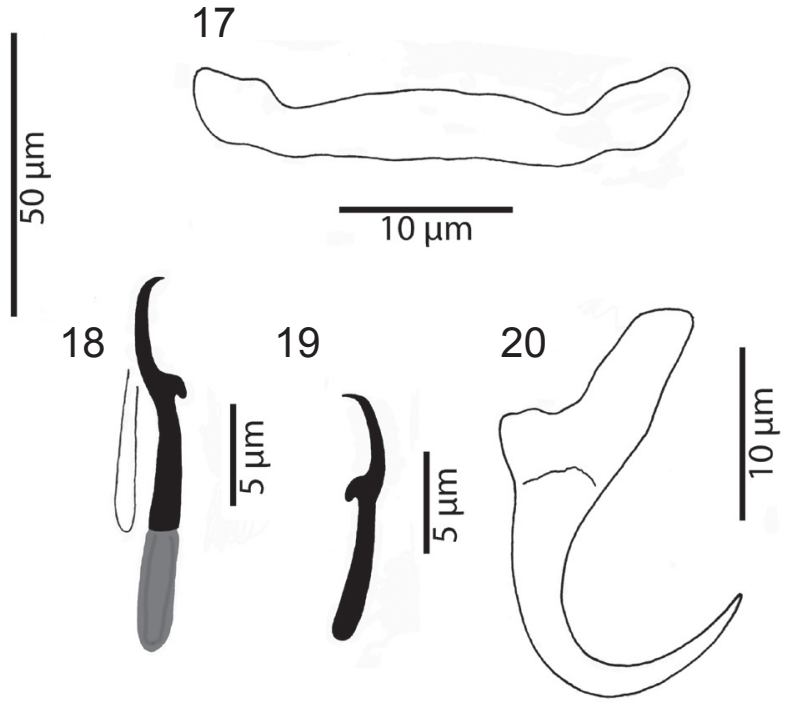

Figs. 12-20. Marumbius dorsivaginatus sp. n. from Characidium pterostictum and C. lanei. Fig. 12. Holotype (ventral view). Fig. 13. Male copulatory complex. Fig. 14. Ventral bar. Fig. 15-16. Ventral anchor. Fig. 17. Dorsal bar. Fig. 18. Hook pair 2. Fig. 19. Hook pair 1. Fig. 20. Dorsal anchor.

hook pairs 2-4, 6 and 7 composed by 1-2 subunits, hook pairs 1 and 5 lacking proximal subunit, length of proximal subunits (when present) varying according to hook pair, completely or partially overlapping gonads, and MCO represented by an incomplete coil of a sclerotized tube articulated to the accessory piece by a copulatory ligament. Only the Neotropical species of Nothothecium Boeger et Kritsky, 1988, Nothozothecium Boeger et Kritsky, 1988, Nothothecioides Kritsky, Boeger et Jégu, 1997, Enallothecium Kritsky, Boeger et Jégu, 1997 and Odothecium Kritsky, Boeger et Jégu, 1997 present a single dorsal vagina, either lateral or at the body midline. Similar to both species of Marumbius, the species of the above genera also share hooks composed by two subunits, completely or partially overlapping gonads and MCO articulated to the accessory piece by a copulatory ligament. However, the dorsal vaginal opening in species of Nothothecium,
Nothozothecium, Nothothecioides, Enallothecium and Odothecium is usually located lateral to the body midline and the vaginal duct always loops the left intestinal caecum, whereas the vaginal opening in Marumbius spp. is dorsal, on the body midline, and the vaginal duct is short and does not loop the caeca. Marumbius spp. differ from the species of these genera also by lacking the proximal subunit in hooks pair 1 and 5 .

\section{Marumbius dorsivaginatus sp. $\mathrm{n}$.}

Figs. 12-20, 32, 35, 37, 38

Description (based on 25 specimens): Body 242 $(206-275 ; n=6)$ long; greatest width $72(27-99 ; n=10)$ at level of gonads. Cephalic lobes moderately developed; each lobe with 1-2 head organs. Eyespots 4, accessory granules scarce in cephalic region. Pharynx subspherical, $27(14-36 ; n=21)$ in diameter. 


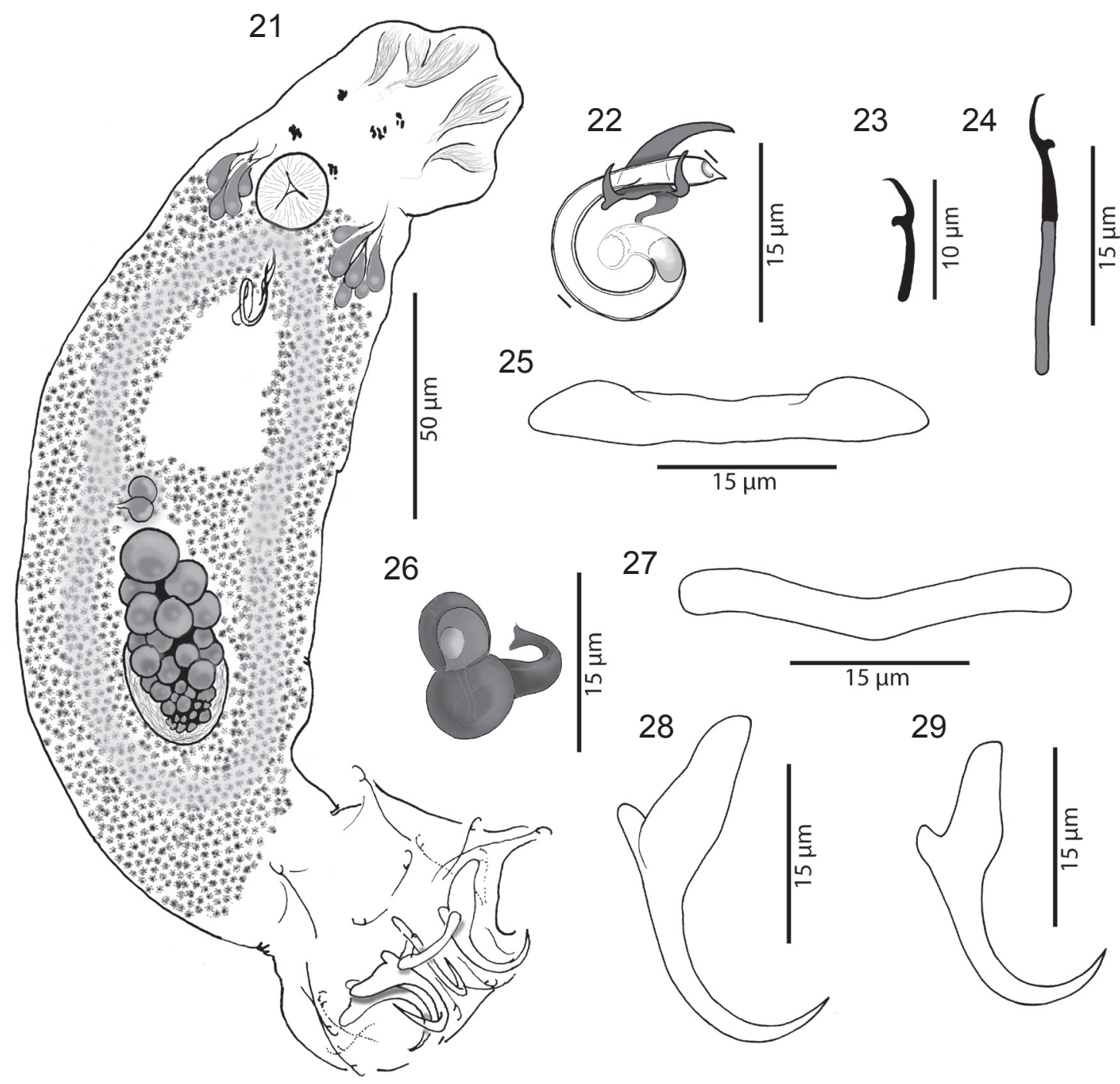

Figs. 21-29. Marumbius amplexus sp. n. from Characidium pterostictum and C. lanei Fig. 21. Composite (ventral view). Fig. 22. Male copulatory complex. Fig. 23. Hook pair 1. Fig. 24. Hook pair 2. Fig. 25. Ventral bar. Fig. 26. Vagina. Fig. 27. Dorsal bar. Fig. 28. Ventral anchor. Fig. 29. Dorsal anchor.

Testis ovate, $40(34-52 ; \mathrm{n}=3)$ long, $15(14-19 ; \mathrm{n}=3)$ wide; vas deferens looping left intestinal caecum; seminal vesicle elongate; prostatic reservoir not observed. $\mathrm{MCO}$ 24 (21-28; $\mathrm{n}=18)$ long, an incomplete loop; base of MCO wide, funnel shaped; accessory piece a rod-shape piece (distally blunt, proximally spoon-like) with an elongate flap on its proximal two thirds. Germarium elongate, $39(35-44 ; \mathrm{n}=3)$ long, $16(12-18 ; \mathrm{n}=3)$ wide. Uterus lateral to seminal vesicle. Vaginal pore single, dorsal; vagina non-sclerotized, inconspicuous. Vitellaria dense.

Haptor $39(17-55 ; \mathrm{n}=19)$ long, $55(24-72 ; \mathrm{n}=19)$ wide; bilaterally expanded. Hooks similar in shape, with depressed thumb, straight shaft, short point (hook measurements in Table 3). Ventral anchor $13(11-15 ; \mathrm{n}=10)$ long, base $6(4-7 ; \mathrm{n}=10)$ wide, delicate, with poorly differentiated roots, straight shaft, point delicate, wavy. Dorsal anchor $23(20-26 ; n=10)$ long, base $13(12-15$; $\mathrm{n}=11)$ wide, with short deep root, elongate superficial root, shaft and point evenly curved. Ventral bar 17 (15-18; $\mathrm{n}=15$ ) long, with slightly expanded ends. Dorsal bar 28 $(23-31 ; n=15)$ long, with slightly expanded ends. Eggs ovate, with smooth shell, short polar filament.

Type host: Characidium pterostictum Gomez.

Other host: Characidium lanei Travassos.

Site of infection: Gills.

Type locality: Rio Marumbi, municipality of Morretes, Paraná, Brazil (25⒉ $\left.27^{\prime} 7^{\prime \prime} \mathrm{S} ; 45^{\circ} 49^{\prime} 67^{\prime \prime} \mathrm{W}\right)$, in March and August 2010 and May 2011 (holotype collected on 18 March 2010).

Prevalence: C. pterostictum $87 \%$ (99/114), C. lanei $21 \%$ $(16 / 77)$.

Specimen deposited: Holotype (CHIOC 37893), 24 paratypes (CHIOC 37884-37892; 37894-37895; USNPC 107191-107192; HWML 49864 ( $\mathrm{n}=5$ ); IPACS M - 543). 
Table 3. Measurements (in micrometers) of hooks of Marumbius dorsivaginatus sp. $\mathrm{n}$.

\begin{tabular}{lcccccccc} 
& \multicolumn{3}{c}{ Total } & \multicolumn{4}{c}{ Subunit 1 of shank } \\
\cline { 2 - 9 } & $\mathrm{n}$ & $\operatorname{mean}$ & $\min$ & $\max$ & $\mathrm{n}$ & mean & $\min$ & $\max$ \\
\hline Hook 1 & - & - & - & - & 13 & 12 & 10 & 13 \\
Hook 2 & 11 & 20 & 19 & 22 & 11 & 14 & 13 & 15 \\
Hook 3 & 11 & 20 & 17 & 23 & 11 & 13 & 12 & 15 \\
Hook 4 & 10 & 20 & 16 & 22 & 10 & 14 & 12 & 15 \\
Hook 5 & - & - & - & - & 13 & 13 & 11 & 15 \\
Hook 6 & 7 & 17 & 16 & 18 & 13 & 13 & 11 & 14 \\
Hook 7 & 4 & 17 & 16 & 18 & 13 & 13 & 12 & 13 \\
\hline
\end{tabular}

Ety mology: The specific name is derived from the position of the vagina in this species (dorsum in Latin = dorsal; vagina in Latin = vagina)

Remarks. The species presents unequal anchor pairs with a reduced ventral pair that presents a delicate point, often distorted in mounted specimens.

Marumbius amplexus sp. n. Figs. 21-29, 36, 39, 40

Description (based on four specimens): Body fusiform. Cephalic lobes moderately developed; each lobe with 2-3 head organs. Eyespots 4, accessory granules present. Pharynx subspherical, $21(19-24 ; n=2)$ wide.

Testis ovate; vas deferens, seminal vesicle, prostatic reservoir not observed. MCO $23(21-24 ; n=2)$ long, an incomplete loop, counterclockwise; base of MCO with slightly sclerotized, elongate, cylindrical base; accessory piece hook-shaped, with proximal support for MCO. Vitellaria dense; vagina mid-dorsal, composed by two sclerotized, spherical subunits.

Haptor $70(64-76 ; n=3)$ long, $115(95-140 ; n=3)$ wide; laterally expanded. Hooks similar in shape, with depressed thumb, straight shaft, short point; hook pair 4 significantly longer than remaining hooks; hook measurements in Table 4. Ventral anchor $27(22-29 ; n=3)$ long, base $13(12-15 ; n=3)$ wide, with well differentiated roots; superficial root elongate; deep root short; shaft, point evenly curved. Dorsal anchor $32(29-33 ; n=3)$ long, base $17(17-18 ; \mathrm{n}=3)$ wide, with short deep root, elongate superficial root, shaft and point evenly curved. Ventral bar 37 (35-39; n =3) long, with slightly expanded ends. Dorsal bar $28(24-31 ; n=2)$ long, with slightly expanded ends. Eggs not observed.

Type and only host: Characidium lanei Travassos.

Site of infection: Gills.

Type locality: Rio Marumbi, municipality of Morretes,

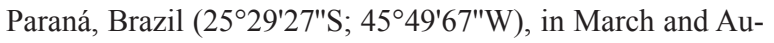
gust 2010 and May 2011 (holotype collected on 11 August 2010).

Prevalence: $10 \%(8 / 77)$.

Specimen deposited: Holotype (CHIOC 37897 ) and 3 paratypes (CHIOC 37896, IPCAS M - 544; USNPC 107197).

Etymology: The specific name is derived from the mor-
Table 4. Measurements (in micrometers) of hooks of Marumbius amplexus sp. $\mathrm{n}$.

\begin{tabular}{lcccccccc} 
& \multicolumn{3}{c}{ Total } & \multicolumn{4}{c}{ Subunit 1 of shank } \\
\cline { 2 - 9 } & $\mathrm{n}$ & mean & $\min$ & $\max$ & $\mathrm{n}$ & mean & min & max \\
\hline Hook 1 & - & - & - & - & 3 & 13 & 11 & 14 \\
Hook 2 & 3 & 28 & 22 & 33 & 3 & 13 & 13 & 14 \\
Hook 3 & 3 & 23 & 18 & 26 & 3 & 13 & 12 & 14 \\
Hook 4 & 3 & 36 & 21 & 45 & 3 & 14 & 14 & 14 \\
Hook 5 & - & - & - & - & 2 & 14 & 13 & 14 \\
Hook 6 & 2 & 18 & 18 & 19 & 2 & 12 & 11 & 13 \\
Hook 7 & 3 & 26 & 17 & 36 & 3 & 14 & 13 & 14 \\
\hline
\end{tabular}

phology of the hook pair 4, which projects laterally conferring a haptor morphology that appears to be ready to embrace the gill filament (amplexus in Latin = to embrace).

Remarks. Marumbius amplexus can be easily distinguished from the type and the only other species in the genus, $M$. dorsivaginatus, by the presence of hook pair 4 conspicuously longer than the remaining hook pairs, by the presence of anchors of similar shape and size, and by the presence of a sclerotized distal vaginal complex composed by two subspherical subunits. Contrary to $M$. dorsivaginatus, $M$. amplexus is relatively rare and is known solely from $C$. lanei.

We decided to describe and propose M. amplexus despite the fact that only few specimens were available. Marumbius amplexus sp. n. represents the second species of the newly proposed Marumbius and provides additional evidence for the validity and monophyly of the genus. We unsuccessfully attempted to increase the number of collected specimens of $M$. amplexus through extensive collection of the host fish species in the type locality, which included two years and several year seasons.

The description, although based on few specimens, which did not enable us to observe well the internal organs and systems, provides enough details and precision to allow subsequent identification of specimens and the congeneric status of the new species and $M$. dorsivaginatus. As a consequence, the proposal of Marumbius is, in our opinion, more robust and provides more stability to the classification of Neotropical Dactylogyridae.

\section{Cacatuocotyle paranaensis Boeger, Domingues et Kritsky, 1997}

Remarks. A single specimen of $C$. paranaensis (CHIOC 37898) was recovered from one $C$. lanei of more than 181 specimens of Characidium spp. (77 C. lanei, 114 C. pterostictum and 2 Characidium sp.). All morphological characters of this specimen are in accordance with the original description.

\section{DISCUSSION}

Despite the fact that no analysis on the community history of the fauna of Monogenoidea that parasitizes species 

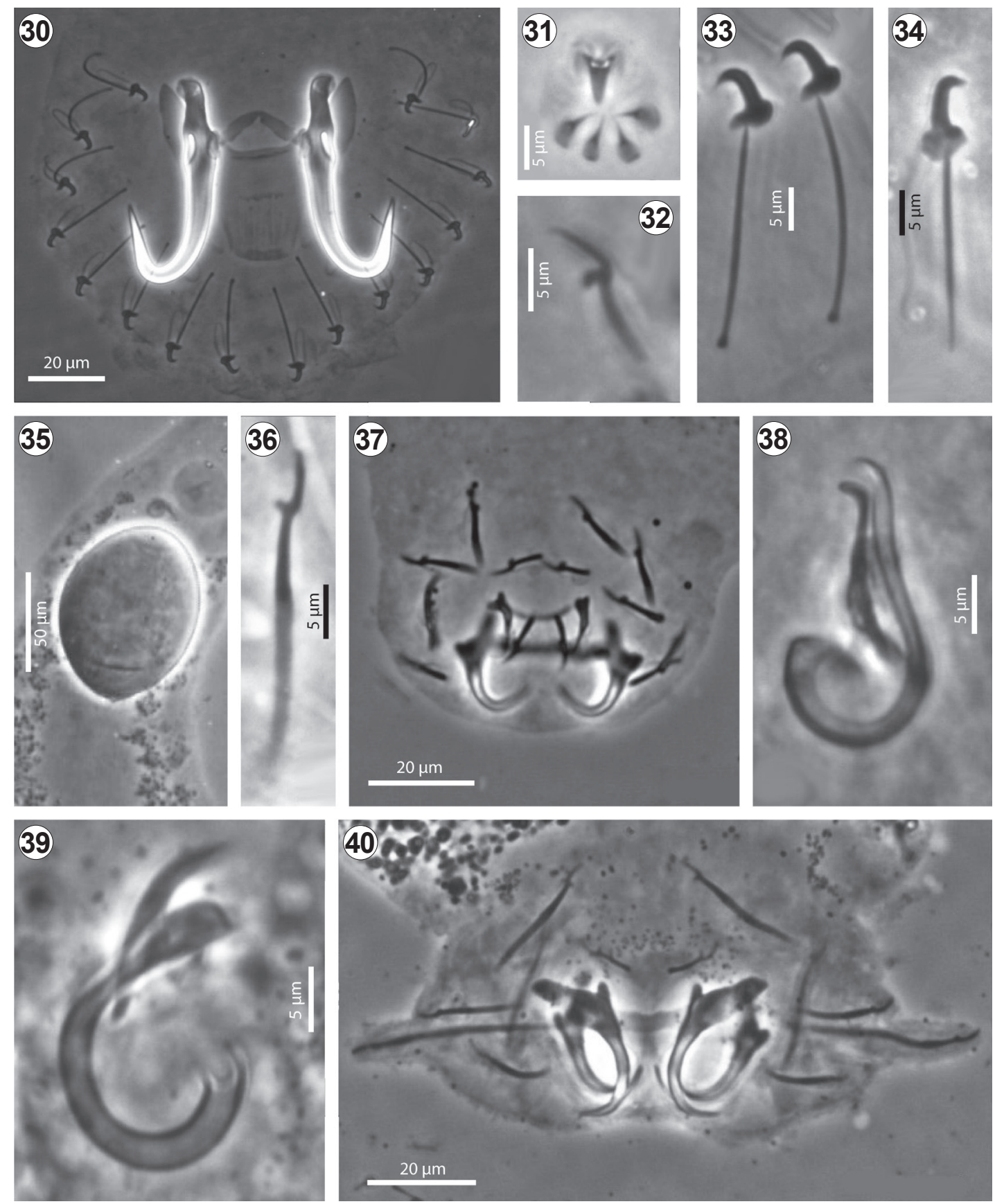

Figs. 30-40. Phase contrast micrographs of the haptoral structures of Monogenoidea from Characidium spp. Fig. 30. Haptoral structures of Gyrodactylus carolinae sp. n. Fig. 31. Male copulatory organ of G. carolinae sp. n. Fig. 32. Hook 5 of Marumbius dorsivaginatus sp. n. Fig. 33. Hooks of G. carolinae sp. n. Fig. 34. Hook of Gyrodactylus inesperatus sp. n. Fig. 35. Egg of M. dorsivaginatus sp. n. Fig. 36. Hook pair 2 of Marumbius amplexus sp. n. Fig. 37. Haptoral structures of M. dorsivaginatus sp. n. Fig. 38. Copulatory complex of $M$. dorsivaginatus sp. n. Fig. 39. Copulatory complex of M. amplexus sp. n. Fig. 40. Haptoral structures of $M$. amplexus sp. n.

of Characidium exists, it is clearly composed by multiple lineages, some of distant relationships, suggesting complex origins. Species of Marumbius and Cacatuocotyle are known solely from species of Characiformes, which suggests a longer history of association with fishes of this order. Marumbius sp. are known solely from species of Characidium (Crenuchidae), whereas Cacatuocotyle was originally proposed based on parasites from Characidium by Boeger et al. (1997) from South Brazil and subsequent species were described from Astyanax sp. from Mexico (Mendoza-Franco et al. 2012).

Species of Urocleidoides sensu stricto (see Kritsky et al. 1986), not collected in this study, are known solely from the gills of Characidium caucanum Eigenmann as 
Urocleidoides anops Kritsky et Thatcher, 1974 from Colombia. This genus is known to contain species parasitising fishes from different taxonomic groups from three orders (Characiformes, Cyprinodontiformes and Gymnotiformes) within the Neotropics (see Mizelle and Price 1964, Kritsky et al. 1986, Jogunoori et al. 2004, MendozaFranco and Reina 2008, Rosim et al. 2011).

Gyrodactylids from Characidum spp. also appear to compose distinct lineages. As suggested in this study, $G$. carolinae is likely to be a member of a lineage of Gyrodactylus in which most members parasitize poeciliid fishes (Cyprinodontiformes) in the Neotropics. This phenotypic and genetic proximity suggests that the association of this parasite lineage with either cyprinidontiform or characiform fishes in the Neotropics is likely associated with at least one host switch event between these distantly related fish clades. In contrast, $G$. inesperatus is apparently not a member of this lineage or any other known lineage of Neotropical Gyrodactylus.

\section{REFERENCES}

Agosta S.J., Janz N., Brooks D.R. 2010: How specialists can be generalists: resolving the 'Parasite Paradox' and implications for emerging infectious disease. Zoologia 27: 151-162.

Altschul S.F., Madden T.L., Schaffer A.A., Zhang J., Zhang Z., Miller W., Lipman D.J. 1997: Gapped BLAST and PSIBLAST: a new generation of protein database search programs. Nucl. Acids Res. 25: 3389-3402.

Álvarez I., Wendel J.F. 2003: Ribosomal ITS Sequences and Plant Phylogenetic Inference. Mol. Phylog. Evol. 29: 417-434.

Boeger W.A., Domingues M.V., Kritsky D.C. 1997: Neotropical Monogenoidea. 32. Cacatuocotyle paranaensis n. g., n. sp. (Dactylogyridae, Ancyrocephalinae) from Characidium spp. (Teleostei, Characidae) from the State of Parana, Brazil. Syst. Parasitol. 36: 75-78.

Boeger W.A., Kritsky D.C, Belmont-Jegú E. 1994: Neotropical Monogenoidea. 20. Two new species of oviparous Gyrodactylidae (Polyonchoinea) from loricariid catfishes (Siluriformes) in Brazil and the phylogenetic status of Oogyrodactylidae Harris. J. Helmintol. Soc. Wash. 6: 30-40.

Boeger, W. A., Kritsky, D. C., Pie, M. R. 2003: Context of diversification of the viviparous Gyrodactylidae (Platyhelminthes, Monogenoidea). Zool. Scri. 32: 437-448.

Brooks D.R. 1993: Extending the symbiotype concept to host voucher specimens. J. Parasitol. 79: 631-633.

Cable J., Harris P.D., Tinsley R.C., Lazarus C.M. 1999: hylogenetic analysis of Gyrodactylus spp. (Platyhelminthes: Monogenea) using rDNA sequences. Can. J. Zool. 77: 1439-1449.

Cable J., van Oosterhout C., Barson N., Harris P.D. 2005: Gyrodactylus pictae n. sp. (Monogenea: Gyrodactylidae) from the Trinidadian swamp guppy Poecilia picta Regan, with a discussion on species of Gyrodactylus von Nordmann, 1832 and their poeciliid hosts. Syst. Parasitol. 60: 159-164.

Coleman A.W. 2007: Pan-eukaryote ITS2 homologies revealed by RNA secondary structure. Nucl. Acids Res. 35: 3322-3329.

Cunningham C.O. 1997: Species variation within the internal transcribed spacer (ITS) region of Gyrodactylus (Monogenea:
The fauna of Monogenoidea of Characidium spp. provides additional support for the recent proposal that ecological fitting (Janzen 1985) through host-switching (see Agosta et al. 2010) is prevalent in parasite community structuring and diversification. Hoberg and Brooks (2008) suggested that the majority of host-parasites associations result from a complex macroevolutionary mosaic involving both co-evolution and colonization. Evidences of host-switching are extensive in the structuring of the parasite community of Characidium spp. not only within Gyrodactylidae, as suggested by Boeger et al. (2003), but also among species of Ancyrocephalinae.

Acknowledgements. Rodrigo Neves, Mariana Braga, Emanuel Ranzzolini and Delane Kritsky provided field support during collections in the State of Paraná. Vinícius Abilhoa identified the host species. This study was funded by the Conselho Nacional de Desenvolvimento Científico e Tecnológico (CNPq). WAB is a research fellow of CNPq; LP and RCF received a scholarship from the Coordenação de Aperfeiçoamento de Pessoal de Nível Superior (CAPES) and RTV received a scholarship from CNPq.
Gyrodactylidae) ribosomal RNA genes. J. Parasitol. 83: 215219.

Edgar R.C. 2004: MUSCLE: multiple sequence alignment with high accuracy and high throughput. Nucl. Acids Res. 32: 17921797.

Eiras J.C., Takemoto R.M., Pavanelli G.C., Adriano E.A. 2011: About the biodiversity of parasites of freshwater fish from Brazil. Bull. Eur. Assoc. Fish Pathol. 31: 161-168.

García-VÁsquez A., Shinn A.P., Bron J.E. 2012: Development of a light microscopy stain for the sclerites of Gyrodactylus von Nordmann, 1832 (Monogenea) and related genera. Parasitol. Res. 110: 1639-1648.

Hansen H., Jorgensen A., Mo T.A. 2012: Spin-off from routine parasite diagnostics of Atlantic salmon; first report of Gyrodactylus alexanderi in Norway. Bull. Eur. Assoc. Fish Pathol. 32: 14-18.

Hoberg E.P, Brooks D.R. 2008: A macroevolutionary mosaic: episodic host-switching, geographical colonization and diversification in complex host-parasite systems. J. Biogeogr. 35: $1533-1550$

Humason G.L. 1979: Animal Tissue Techniques. 4th Ed. W.H. Freeman and Co. (Sd) San Francisco, CA. 468 pp.

Huyse T., Audenaert V., Volckaert F.A. 2003: Speciation and host-parasite relationships in the parasite genus Gyrodactylus (Monogenea, Platyhelminthes) infecting gobies of the genus Pomatoschistus (Gobiidae, Teleostei). Int. J. Parasitol. 33: $1679-1689$.

Huyse T., Malmberg G. 2004: Molecular and morphological comparisons between Gyrodactylus ostendicus n. sp.(Monogenea: Gyrodactylidae) on Pomatoschistus microps (Krøyer) and G. harengi Malmberg, 1957 on Clupea harengus membras L. Syst. Parasitol. 58: 105-113.

JANZEN D.H. 1985. On ecological fitting. Oikos. 45: 308-311.

Jogunoori W., Kritsky D.C., Venkatanarasaiah J. 2004: Neotropical Monogenoidea. 46. Three new species from the gills of introduced aquarium fishes in India, the proposal of Heterotylus n. g. and Diaphorocleidus n. g., and the reassignment 
of some previously described species of Urocleidoides Mizelle and Price, 1964 (Polyonchoinea: Dactylogyridae). Syst. Parasitol. 58: $115-124$.

Kritsky D.C., Boeger W.A., Popazogo F. 1995: Neotropical Monogenoidea. 22. Variation in Scleroductus species (Gyrodactylidea, Gyrodactylidae) from Siluriformes fishes of southeastern Brazil. J. Helm. Soc. Wash. 62: 53-56.

Kritsky D.C., Fritts T.H. 1970: Monogenetic trematodes from Costa Rica with the proposal of Anacanthocotyle gen. n. (Gyrodactylidae: Isancistrinae). Proc. Helm. Soc. Wash. 37: 63-68.

Kritsky D.C., Leiby P.D., Kayton R.J. 1978: A rapid stain technique for the haptoral bars of Gyrodactylus species (Monogenea). J. Parasitol. 64: 172-174.

Kritsky D.C., Mizelle J.D. 1968: Studies on monogenetic trematodes. XXXV. Some new and previously described North American species of Gyrodactylus. Am. Midl. Nat. 79: 205215.

Kritsky D.C., Thatcher V.E. 1974: Monogenetic trematodes (Monopisthocotylea: Dactylogyridae) from freshwater fishes of Colombia, South America. J. Helminthol. 48: 59-66.

Kritsky D.C., Thatcher V.E., Boeger W.A. 1986: Neotropical Monogenea. 8: Revision of Urocleidoides (Dactylogyridae, Ancyrocephalinae). Proc. Helm. Soc. Wash. 53: 1-37.

Malmberg G. 1970: The excretory systems and the marginal hooks as a basis for the systematics of Gyrodactylus (Trematoda, Monogenea). Ark. Zool. 23: 1-235.

Mendoza-Franco E.F., Caspeta-Mandujano J.M., SalgadoMaldonado G. 2012: New species of Cacatuocotyle (Monogenoidea, Dactylogyridae) parasitizing the anus and the gill lamellae of Astyanax aeneus (Pisces, Ostariophysi: Characidae) from the Rio Lacantún basin in the Biosphere Reserve of Montes Azules, Chiapas, Mexico. Parasitol. Res. 112: 199-205.

Mendoza-Franco E.F., Reina R.G. 2008: Five new species of Urocleidoides (Monogenoidea) (Mizelle and Price 1964) Kritsky, Thatcher, and Boeger, 1986, parasitizing the gills of Panamanian freshwater fishes. J. Parasitol. 94: 793-802.

Mizelle J.D. 1936: New species of trematodes from the gills of Illinois fishes. Am. Midl. Nat. 17: 785-806.

Mizelle J.D., Klucka A.R. 1953: Studies on monogenetic trematodes. XIV. Dactylogyridae from Wisconsin fishes. Am. Midl. Nat. 49: 720-733.

Mizelle J.D., Kritsky D.C. 1967: Studies on monogenetic trematodes. XXXIII. New species of Gyrodactylus and a key to the North American species. Trans. Am. Microsc. Soc. 86: 390401.

Mizelle J.D., Price C.E. 1963: Additional haptoral hooks in the genus Dactylogyrus. J. Parasitol. 49: 1028-1029.

Mizelle J.D., Price C.E. 1964: Studies on monogenetic trematodes. XXVII. Dactylogyrid species with the proposal of Urocleidoides n. gen. J. Parasitol. 50: 579-584.
Nei, M., Kumar S. 2004: Prospects for inferring very large phylogenies by using the neighbor-joining method. Proc. Natl. Acad. Sci USA 101: 11030-11035

Paladini G., Huyse T., Shinn A.P. 2011: Gyrodactylus salinae n. sp. (Platyhelminthes, Monogenea) infecting the south European toothcarp Aphanius fasciatus (Valenciennes) (Teleostei, Cyprinodontidae) from hypersaline environment in Italy. Parasites \& Vectors 4: 100.

Richards G.R., Chubb J.C. 1995: Trichrome staining of Gyrodactylus sclerites and soft tissues following fixation in ammonium picrate-glycerin, including an improved rendition of the haptoral bars of Gyrodactylus turnbulli. J. Helminthol. 69: $149-154$.

Richards G.R., Veltkamp C.J., Chubb J.C. 2000: Differentiation of Gyrodactylus bullatarudis Turnbull, 1956 and G. rasini Lucky, 1973 (Monogenea) with reassignment of Gyrodactylus bullatarudis Turnbull, 1956 sensu Harris (1986) to G. rasini. J. Nat. Hist. 34: 341-353.

Rosim D.F., Mendoza-Franco E.F., Luque J.L. 2011: New and previously described species of Urocleidoides (Monogenoidea: Dactylogyridae) infecting the gills and nasal cavities of Hoplias malabaricus (Characiformes: Erythrinidae) from Brazil. J. Parasitol. 97: 406-417.

Rubio-Godoy M., Paladini G., García-Vásquez A., Shinn A.P. 2010: Gyrodactylus jarocho sp. nov. and Gyrodactylus xalapensis sp. nov. (Platyhelminthes: Monogenea) from Mexican poeciliids (Teleostei: Cyprinodontiformes), with comments on the known gyrodactylid fauna infecting poeciliid fish. Zootaxa. 2509: 1-29.

Steinke D., Hanner R. 2011: The FISH-BOL Collaborators' Protocol. Mitochondrial DNA. 22: 10-14.

Tamura K., Peterson D., Peterson N., Stecher G., Nei M., KumAR S. 2011: MEGA 5: molecular evolutionary genetics analysis using maximum likelihood, evolutionary distance, and maximum parsimony methods. Mol. Biol. Evol. 28: 2731-2739.

Vaughan D.B., Christison K.W., Hansen H., Shinn A.P. 2010: Gyrodactylus eyipayipi n. sp. (Monogenea: Gyrodactylidae) from Syngnathus acus (Syngnathidae) from South Africa. Folia Parasitol. 57: 11-15.

Zietara M.S., Huyse T., Lumme J., Volckaert F.A. 2002: Deep divergence among subgenera of Gyrodactylus inferred from rDNA ITS region. Parasitology 124: 39-52.

Zietara M.S., Kuusela J., Veselov A. Lumme J. 2008: Molecular faunistics of accidental infections of Gyrodactylus Nordmann, 1832 (Monogenea) parasitic on salmon, Salmo salar L., and brown trout, Salmo trutta L., in NW Russia Syst. Parasitol. 69: $123-135$

Zietara M.S., Lumme J. 2003: The crossroads of molecular, typological and biological species concepts: two new species of Gyrodactylus Nordmann, 1832 (Monogenea: Gyrodactylidae). Syst. Parasitol. 55: 39-52.

Accepted 25 August 2013 